\title{
The Influence of Organizational Culture, and Job Satisfaction on Employee Performance (Case Study on Digital Printing)
}

\author{
R. Joko Sugiharjo \\ Economics and Business Faculty, Management Department \\ Universitas Mercu Buana
}

\begin{abstract}
This study aims to examine the influence of Organizational Culture, and Job Satisfaction on Employee Performance on CV Xpress Digital Printing Tangerang. The object of this study is 70 employees on CV Xpress Digital Printing Tangerang by using quantitative approach. Therefore, the data analysis used is statistical analysis in the form of multiple linear regression (SPSS). The results of this study showed that the t Culture Organizational and Job Satisfaction have a significant effect on Employee Performance on CV Xpress Digital Printing.
\end{abstract}

Keywords: Organizational Culture, Job Satisfaction and Employee Performance.

DOI: $10.7176 / \mathrm{EJBM} / 11-12-14$

Publication date: April $30^{\text {th }} 2019$

\section{INTRODUCTION}

Human resources are an important element of a company. Employees are the company's main resource that is required to provide the best service to consumers, so that consumers feel well served and satisfied. If consumers feel dissatisfied, then consumers can make complaints that can damage the company's image. This shows that human resources are very influential on the success of the company in achieving its goals according to Mangkunegara (2013).

An organization is a unit in which there are various individuals who have different backgrounds and work together to achieve organizational goals. The achievement of an organization's goals is greatly influenced by the performance of human resources in the organization. Performance is the result of work in quality and quantity that is achieved by someone in carrying out the task or work that is in accordance with the responsibilities that have been given to him and is the work that has been achieved by someone with a predetermined standard. With these standards it is expected that a person's performance in an organization can produce good quality work and the number of jobs that are in accordance with the standard (Haryani 2013).

According to Sedarmayanti (2014) performance is the result of the work of a worker, a management process or an organization as a whole, where the results of the work must be demonstrated concretely and can be measured compared to predetermined standards. Survival and growth of the company is not only determined by the success in managing finances based solely on the strength of capital or money, but also on the success of managing human resources which means that companies must be able to unite the perceptions or perspectives of employees and company leaders in order achieving company goals, including good mental formation with high dedication and satisfaction with its work, providing good direction and coordination in working by a leader to subordinate it.

To achieve its goals, the CV Xpress Digital Printing Tangerang face many obstacles such as instability of work culture, job satisfaction, employee issues and promotion in the service of customer satisfaction. Along with the demands of current human resources needs, the company must change according to developments that grow in the community. The key to success of a company in order to be able to meet the demands of human resources is to lie in its human factors. Every employee in the company must have the competencies and skills demanded by his field of work so that he can show optimal work. Seeing the importance of employee performance to support the work of an organization or company, the company needs to create an organizational culture and meet the job satisfaction of its employees.

A strong culture within the organization encourages its members to act and behave according to what the organization expects. By obeying the rules and policies that exist within the organization, it is expected to optimize the performance and productivity of employees to achieve the goals. Organizational culture in any company or organization emerged from the life journey of the founders of the organization or member of the organization. They play a role in decision making or determining the direction of organizational strategy. Job satisfaction is related to a person's feelings or attitudes about the job itself, salary, opportunities for promotion or education, supervision, coworkers, workloads, and others. (Hughes, 2012). This is evident in the positive nature of the employee's work and everything that is faced in his work environment. Every employee has a different level of satisfaction according to the values that apply to him. The more aspects in the work that are in accordance with the desires and aspects of the individual self, then there is a tendency for the higher level of satisfaction of work. Based on the above 
understanding, it can be concluded that job satisfaction is a person's feelings for their work, this means that the concept of job satisfaction can be seen as a result of employee interactions with their work environment.

The phenomenon is that there are problems that not yet fully CV Xpress Digital Printing employees perform their functions and duties properly. This is evidenced by the results of work that is not maximal in carrying out its work, which is obtained as much as $70 \%$ of employees feel dissatisfied with their work.

\section{LITERATURE REVIEW, FRAMEWORK, AND HYPOTHESES}

\section{Human Resource Management}

Human resource management is an inseparable part of company management, which is one of the determinants of the company's success in achieving company goals. In addition, Human Resource Management is part of the science of management, often said to be a management science that studies the process of planning, organizing, coordinating, implementing and supervising the procurement, development, remuneration, merging, maintenance, and separation of labor in order to achieve company goals. In order to make the understanding of human resource management clearer, the author will provide several definitions from several experts as follows:

According to Mangkunegara (2013) human resource management is a planning, organizing, coordinating, implementing, and monitoring of procurement, development, rewards, integration, maintenance and separation of labor in order to achieve organizational goals.

\section{Conceptual Framework and Hypotheses Development}

According to Sunyoto (2012), organizational culture is a series of feelings and perceptions of the various workers who can change from time to time and from one worker to another worker. Based on research conducted by Fauzi (2016) examined the relationship Organizational Culture and Job satisfaction to employee performance and organizational commitment. The results of this study state that there is a positive and significant impact between organizational culture and employee performance. In a study conducted by Victor (2017) on the Effect of Work Orientation and Organizational Culture on Employee Performance it is known that the results of this study simultaneously the organizational culture have a significant effect on Performance. While based on previous research by Kurniawan (2017) about Organizational Culture, Work Motivation and Compensation for Employee Performance. The results of the study state that organizational culture variables have a positive and significant effect on employee performance.

\section{Hypotheses}

Sugiyono $(2010$; 93) The hypothesis is a temporary answer to the research problem formulation, therefore the formulation of research problems is usually arranged in the form of question sentences so the hypothesis can also be expressed as a theoretical answer to the research problem formulation, before the empirical answer. Based on the explanation of work theory, previous research and the conceptual framework above, the research hypothesis can be formulated as follows:

1. Organizational culture has a positive and significant effect on employee performance on CV Xpress Digital Printing

2. Job satisfaction has a positive and significant effect on employee performance on CV Xpress Digital Printing

\section{Metodology}

Research design is causal research. According to Sugiyono (2013) causal is a causal relationship, that is, the independent variable influences the dependent variable. This is a study to determine the effect of two independent variables (exogenous), namely organizational culture and job satisfaction, on one dependent variable (endogenous), namely employee performance. This study aims to examine whether or not the influence of one or several variables (Independent variables) on the other (dependent variable), namely Organizational Culture (X1), Job Satisfaction (X2), on Employee Performance (Y) on CV Xpress Digital Printing. The population is all employees of CV Xpress Digital Printing, Tangerang, are 70 employees. The sample used in this study uses saturated samples, because the researchers used all members of the population that is 70 respondents. All respondent asked to answer the questions in the questionnaire as a technique of data collection.

\section{RESULTS AND DISCUSSION}

\section{Influence of Organizational Culture on Employee Performance}

Based on the results of testing the first hypothesis which shows that organizational culture has a positive and significant effect on employee performance. it can be said that organizational culture has a significance level of 0.004 , which is a value smaller than the significance level of 0.05 , so the hypothesis accepted is Ha1. So it can be concluded that the variable organizational culture (X1) has a significant effect employee performance CV Xpress Digital Printing Tangerang City. The results of this hypothesis are also strengthened by Fauzi's research (2016) where the 
results of the study state that organizational culture has a positive and significant effect on employee performance.

\section{Influence of Job Satisfaction on Employee Performance}

Based on the results of testing the second hypothesis which shows that job satisfaction has a positive and significant effect on employee performance, it can be said that job satisfaction has a significance level of 0.001 where the value is smaller than the significance level of 0.05 , then the hypothesis received is Ha2, so it can be concluded that job satisfaction variables (X2) has a significant effect on employee performance CV Xpress Digital Printing Tangerang City. The results of this hypothesis are also strengthened by Suryanto (2017) research where the results of the study state that job satisfaction has a positive and significant effect on employee performance.

\section{Conclusion}

Based on research results and data processing has been done, it can be concluded as follows:

1. Organizational Culture has a positive and significant effect on Employee Performance on CV. Xpress Digital Printing Tangerang City. This means that if the organizational culture increases the employee's performance also increases, whereas if the organizational culture decreases, the employee's performance decreases.

2. Job Satisfaction has a positive and significant effect on Employee Performance of CV. Xpress Digital Printing Tangerang City. This means that if job satisfaction increases, employee performance also increases, whereas if job satisfaction decreases, employee performance decreases.

\section{Suggestion}

Based on the conclusions that have been made, the suggestions that we can give in the study are: 1) Based on the results of the respondents' answers, the suggestions that we can convey are that the company, especially the supervisor, should be able to monitor and motivate their employees so that employees can work optimally. and totality. As well as superiors are expected to be able to always supervise their employees when working or need to do special training for employees so that employees who work in each division in the company can work and complete their work properly and correctly; 2) For further research, it can conduct similar research and it is expected that further researchers can better examine and analyze the influence of organizational culture and job satisfaction on employee performance simultaneously and partially both assisted by independent variables with dependent variables that are likely to be influenced by variables. other variables of this research.

\section{BIBLIOGRAPHY}

Abdullah, Ma'aruf. (2014). Management and Employee Performance Evaluation, Yogyakarta: Aswanda Pressindo. Anonymous, 2013. Definition of Human Resources. Oxford Dictionaries. On: http://www.oxforddictionaries.com/definastion/english/human-resources.

Badriyah, Mila. (2015). Human Resource Management. Bandung: CV Pustaka Setia.

Bangun, Wilson. 2012. Human Resource Management, Bandung: Erlangga.

Dedy, Bambang and Wuryan. (2017). "Employee Perception Regarding the Effect of Employee Competence and Job Satisfaction on Organizational Performance with Government Internal Control Systems and Organizational Values as Moderating Variables ", Scientific Journal and Public Administration, Vol (3), No 2, 99-111.

Dudung.(2016)," Effect of Career Development and Job Satisfaction on Employee Productivity ". Scientific Journal of Management \& Accounting, Vol. 3 Nomor 2, ISSN : 2356-3923.

Durai, P. 2010. Human Resources Management. Pearson Education India. on http://my.safaribooksonline.com/hrorganizational management/97893325 01393/1-introduction-to-human-resource-management/ch1 sub6 xhtm.

Edision, Emron. (2016). Human Resource Management. 1st print. Bandung : Alfabeta.

Fauzi,. (2016)." Effect of Organizational Culture and Job Satisfaction on Employee Performance with Organizational Commitment as Intervening Variables ", Journal of Management Vol.02 No.02.

Haryani. (2013). "The Effect of Justice Distribution and Processual Justice on the Performance of BMT Hudatama Semarang Employees ". Journal of Economics, Management, Accounting. No 35.

Hughes, R. L., Ginnet, R. C., and Curphy, G. J. (2012). Leadership: Enriching Lessons from the Seventh Edition Experience. Jakarta: Salemba Humanika.

Huma Abid, (2014)," Impact of Organizational Culture on Organizational Commitment and Job Satisfaction". European Journal of Business and Management, ISSN 2222-2839 (Online) Vol.6, No.27.

Ibrahim,. (2014). "The Impact of Organizational Culture on Job Satisfaction, Employess Commitment and Turnover Intention”. Advances In Economics and Business. 2(6).

Kasmir. (2015). Human Resource Management (Theory and Practice). 1st print. Jakarta: PT Rajaqrafindo Persada. Kurniawan,. (2017). "Effect of Organizational Culture, Work Motivation and Compensation on Employee Performance ", Journal of Science and Management Research.Vol 6, No 3. 
Mangkunegara, A.A Anwar Prabu. (2010). HR Performance Evaluation. Bandung : Refika Aditama.

Mangkunegara, A.A Anwar Prabu. (2012). HR Performance Evaluation. Bandung : Refika Aditama.

Mangkunegara, A.A Anwar Prabu .(2013) Human Resource Management.

Meithiana. (2017)." The Effect Of Organizational Culture,Environmental Work, Leadership Style On The Job Satisfaction and Its Impacr On The

Mukeri. (2016),"Effect of Organization Culture and Organization Commitment on Employee Performance with Organizational Citizenship Behavior as Mediation".

Putu Anggita, Victor P. (2017)." Effect of Work Orientation and Organizational Culture on Employee Performance " ,Journal of EMBA Vol.5 No.2 17, pp. 1193 -1204.

Rodiathul, M. Djudi. (2016). "Effect of Organizational Culture on Employee Performance at PT Karya Indah Buana Surabaya ". Business Administration Journal.|Vol. 31 No.1.

Sugiyono. (2014). Quantitative Research Methods. Qualitative and R \& D. Bandung : Alfabeta CV.

Sutrisno, Edy. (2015). Human Resource Management. 5th print. Jakarta: Kencana.

Syauta, (2012). "The Influence of Organizational Culture, Organizational Commitment to Job Statisfaction and Employee Performace”. International Journal of Business and Management Invention, ISSN (online): 23198028 .

Widya, Wendi and Agung Wahyu. (2013). "Effect of Work Environment and Organizational Culture on Job Satisfaction ". Indonesian Science Management Research Journal (JRMSI) Vol. 4, No. 2.

Veithzal Rivai, (2011). Human Resource Management. Jakarta: Rajawal Press.

Victor,. (2012). "Effect of Work Orientation and Organizational Culture on Employee Performance. (Study at PT PLN Persero) ". Manado, EMBA Journal |Vol.5 No.2

Zunaidah. and A.N.A. Budiman. 2014. Analisis Pengaruh Motivasi dan Budaya Organisasi terhadap Kinerja Employees of PT Gas Station Putra Kelana Makmur Group. Journal of Management and Business 12(1): 4554. 